INOBIS: Jurnal Inovasi Bisnis dan Manajemen Indonesia

Volume 2, Nomor 1, Desember 2018

I Made Oka Santika; I Nyoman Nurcaya

\title{
Faktor Kontekstual, Brand Switching, Dan Keputusan Pembelian Operator Seluler di Kota Denpasar
}

\author{
I Made Oka Santika ${ }^{1}$ \\ I Nyoman Nurcaya ${ }^{2}$ \\ ${ }^{1,2}$ Fakultas Ekonomi dan Bisnis Universitas Udayana, Bali, Indonesia \\ email: ichangnur@unud.ac.id
}

\begin{abstract}
In this era there are many mobile operators who offer various services with excellence and uniqueness of its own. Young consumers are more likely to follow trends, so they make operator purchases by alternating. This phenomenon shows that contextual and behavioral factors alternating brands lead to consumer purchase decisions. The purpose of this study is to explain the influence of contextual factors and brand switching on purchasing decisions. This research was conducted on the user of mobile operator in Denpasar City which domiciled in Denpasar City. Sample size taken as many as 120 people with purposive samling method. Data were collected by distributing questionnaires using a 5-point Likert scale to measure 15 indicators. The analysis technique used is multiple linear regression. The result of research indicate that contextual factor variable have positive and significant effect to purchasing decision. Brand switching variables have a positive and significant effect on purchasing decisions. This research is expected to be a consideration for cellular service providers in meeting the needs and desires of consumers and is expected to be used as a subject of further study and add references related to variables studied.
\end{abstract}

Keywords: Contextual Factors, Brand Switching, Purchase Decision

\section{Pendahuluan}

Pada era ini terdapat banyak perusahaan yang menciptakan produk atau jasa yang dapat memenuhi kebutuhan konsumen dengan keunggulan dan keunikannya masing-masing. Dengan keunggulan dan keunikan tersebut akan menimbulkan persaingan yang ketat pada setiap industri yang ada. Jika ingin memenangkan persaingan maka tiap perusahaan harus memiliki keunggulan produk yang ditawarkan, termasuk perusahaan telekomunikasi di Indonesia yang saat ini hampir semua kalangan masyarakat menggunakannya.

Di Indonesia, terdapat banyak operator seluler yang menawarkan berbagai jasanya dengan keunggulan dan keunikannya tersendiri. Biasanya setiap operator memiliki keunggulannya tersendiri, seperti harga lebih murah, tetapi memiliki jangkauan sinyal yang ada pada daerah terbatas, ada pula yang memiliki jangkauan sinyal luas tapi harganya relatif lebih mahal. Konsumen muda biasanya lebih memilih mengikuti trend, jadi biasanya mereka akan melakukan pembelian operator dengan berganti-ganti operator seluler (brand switching). Wijaya dkk. (2014) menyatakan bahwa mahasiswa merupakan salah satu komunitas yang peka akan perkembangan teknologi dan cenderung berganti-ganti produk sesuai perkembangan zaman demi menunjang kebutuhan akan teknologi terkini dan juga sebagai bagian dari gaya hidup.

Saat ini perusahaan operator seluler tidak mengandalkan harga saja, namun berlombalomba menciptakan nilai tambah yang dapat dinikmati pelanggan mereka yang sesuai dengan 
INOBIS: Jurnal Inovasi Bisnis dan Manajemen Indonesia

Volume 2, Nomor 1, Desember 2018

I Made Oka Santika; I Nyoman Nurcaya

keinginan dan kebutuhan mereka. Ketatnya persaingan yang terjadi pada industri telekomunikasi bukan saja dirasakan oleh para operator seluler, tetapi juga para pelanggan. Sehingga masing-masing operator seluler bersaing dengan program promosi mereka yang inovatif dan efektif.

Telepon seluler merupakan salah satu jenis sarana telekomunikasi yang banyak digunakan. Sampai saat ini, telepon seluler tidak hanya digunakan untuk berkomunikasi, namun bisa juga digunakan untuk mendengarkan musik, menonton video , bermain game, mencari informasi, berita dan lainnya di internet (Makwana et al., 2014).

Terlepas mengenai telepon seluler, operator seluler merupakan penyedia jasa dari telepon seluler. Sejalan dengan banyaknya operator seluler saat ini yang beredar di pasaran seperti Telkomsel, Indosat Ooredoo, Tri, XL Axiata, dan Smartfren. Salah satu contoh dari operator seluler yaitu, Telkomsel merupakan perusahaan telekomunikasi seluler tertua di Indonesia. Sesuai dengan usianya, Telkomsel memiliki jumlah pangguna yang paling banyak. Telkomsel memiliki kelebihan pada sektor wilayah. Jaringan Telkomsel lebih luas dibandingkan operator seluler lainnya. Untuk masalah kecepatan jaringan, telkomsel masih berada di peringkat pertama sebagai jaringan tercepat di Indonesia baik 3G maupun 4G.

Perilaku konsumen adalah studi tentang individu, kelompok, atau organisasi dan proses yang mereka gunakan untuk memilih, aman, penggunaan, dan membuang produk, jasa, pengalaman, atau ide untuk memuaskan kebutuhan dan dampak bahwa proses ini terhadap konsumen dan masyarakat (Laddha dan Mayur, 2015). Kotler dan Amstrong (2008:159), mengartikan perilaku konsumen sebagai perilaku pembelian konsumen akhir, baik individu maupun rumah tangga, yang membeli produk untuk konsumsi personal. Suprapti (2010:2), mendefinisikan perilaku konsumen sebagai perilaku yang ditujukkan oleh konsumen dalam mencari, membeli, menggunakan, mengevaluasi, dan membuang produk, dan jasa yang diharapkan akan memenuhi berbagai kebutuhannya. Jadi, perilaku konsumen dapat didefinisikan sebagai tindakan dan kegiatan individu dalam pembelian suatu produk untuk memenuhi kebutuhan dan keinginannya. Seorang pemasar perlu mempelajari dan memahami apa yang dibutuhkan dan diinginkan konsumen, karena konsumen memiliki banyak keragaman yang menarik. Hal tersebut yang menyebabkan setiap kebutuhan dan keinginan konsumen berbeda-beda.

Perilaku pembelian konsumen adalah cara konsumen membeli sesuatu yang mereka butuhkan atau mereka inginkan dan perilaku pembelian konsumen dapat dipengaruhi oleh tren (Mantiaha, 2016). Kotler dan Armstrong (2008:159), mengatakan bahwa pembelian konsumen secara kuat dipengaruhi oleh beberapa faktor, dari karakteristik budaya, sosial dan psikologis. Mempelajari faktor-faktor yang berpengaruh terhadap perilaku pembelian konsumen akan menguntungkan pemasar (Prastiyo, 2016). Perilaku pembelian konsumen juga dapat didefinisikan sebagai cara konsumen dalam memilih produk dari segala macam produk yang ada sesuai dengan keinginannya agar terpenuhinya kepuasan. Sulit bagi pemasar dalam mengetahui perilaku konsumen karena setiap konsumen memiliki perilaku yang berbeda-beda dan perilaku tersebut dapat dipengaruhi oleh banyak faktor. Karena itu, penting bagi pemasar untuk mempelajari dan memahami bagaimana konsumen berperilaku dan faktor-faktor apa yang mempengaruhi agar seorang pemasar dapat memenuhi kebutuhan dan keinginan dari konsumen. Para pemasar perlu mempelajari dan memahami karakteristik budaya, sosial dan psikologis dari konsumen. Perilaku konsumen timbul karena adanya keinginan seseorang yang ditunjukkan dari setiap tindakan yang dilakukan untuk mencapai suatu tujuan yang mampu menimbulkan kepuasan akan suatu kebutuhan dan/atau keinginan konsumen.

Setiap operator bersaing sangat ketat dengan berlomba-lomba menawarkan produknya, sehingga konsumen bisa memilih operator mana yang digunakan sesuai dengan 
INOBIS: Jurnal Inovasi Bisnis dan Manajemen Indonesia

Volume 2, Nomor 1, Desember 2018

I Made Oka Santika; I Nyoman Nurcaya

kebutuhannya. Afzal et al., (2013) menyatakan bahwa brand switching adalah proses di mana konsumen beralih dari penggunaan satu produk ke produk lain namun dalam kategori yang sama. Dalam kehidupan sehari-hari, konsumen beralih dari satu merek ke merek lain meskipun sangat puas dengan produk tersebut.

Brand Switching merupakan proses beralih dari satu produk ke produk lain tetaapi dalam kategori yang sama oleh konsumen (Afzal et al., 2013). Brand Switching ditandai dengan adanya perbedaan signifikan antar merek. Konsumen dalam hal ini tidak mengetahui banyak mengenai kategori produk yang ada. Para pemasar dengan demikian perlu mendiferensiasikan keistimewaan mereknya untuk menjelaskan merek tersebut. Perpindahan merek (brand switching) juga ditandai dengan keterlibatan yang rendah (low involvement). Konsumen tidak melalui tahap-tahap keyakinan, sikap atau perilaku yang normal. Konsumen tidak secara ekstensif mencari informasi mengenai merek, melainkan merupakan penerima informasi pasif. Konsumen tidak membentuk keyakinan merek tetapi memilih suatu merek karena merek tersebut terasa akrab (Kurniawan, 2016).

Brand Switching adalah saat dimana seorang konsumen atau sekelompok konsumen berpindah kesetiaan dari satu merek sebuah produk tertentu ke merek produk lainnya. Menurut Junaidi dan Dharmmesta (2002) dalam Loprang (2015), perpindahan merek merupakan gambaran dari beralihnya konsumen dari suatu produk ke produk lainnya. Hal ini disebabkan karena konsumen melakukan perbandingan antara merek satu dengan merek yang lain pada saat ia mengevaluasi merek tertentu atau pada saat ia membentuk sikapnya terhadap merek (Laroche et al., 1994 dalam Loprang 2015). Perpindahan merek merujuk pada alasan konsumen untuk mencoba pola pembelian yang diidentikkan dengan perubahan atau pergantian dari satu merek ke merek yang lain. Munculnya banyak merek mendorong konsumen untuk mencari variasi lain dari produk yang sama dengan merek berbeda (Khasanah dan Kuswati, 2013).

Peralihan merek yang dikenal sebagai brand jumping adalah proses memilih untuk beralih dari penggunaan rutin suatu produk atau merek agar tetap menggunakan produk yang berbeda namun serupa (Awogbemi et al., 2012). Perpindahan merek dapat muncul karena adanya kebutuhan mencari variasi (Suhersono dkk. 2013). Perpindahan merek dapat juga dikarenakan ketidakpuasan konsumen terhadap suatu produk dan beralih ke produk pesaing yang dirasakan lebih baik dari produk sebelumnya (Pantawis dan Rudi, 2016).

Perpindahan merek atau brand switching merupakan terjadinya perpindahan kesetian merek produk satu ke merek produk yang lainnya oleh seorang konsumen atau sekelompok konsumen yang disebabkan oleh adanya evaluasi dan pertimbangan dari konsumen.

Telekomunikasi seluler saat ini sudah menjadi suatu kebutuhan yang utama bagi masyarakat Indonesia, khususnya telekomunikasi seluler berbasis Global System for Mobile (GSM) yang sudah akrab di telinga masyarakat Indonesia. Pengguna GSM sendiri tidak terbatas hanya pada kota-kota besar tetapi sudah mencapai pelosok-pelosok daerah di seluruh Indonesia.

Fenomena seperti ini menunjukkan bahwa faktor kontekstual (keluarga, teman, gaya hidup, citra diri, dan citra merek) merupakan salah satu faktor yang dapat mempengaruhi perilaku konsumen dalam melakukan keputusan pembelian. Jika tersedia beberapa merek di pasaran, perilaku berganti-ganti merek (brand switching) seperti rasa penasaran, kemudahan untuk beralih, banyaknya pilihan, promosi, harga dan kekecewaan pada produk yang digunakan saat ini dapat mengakibatkan terjadinya keputusan pembelian konsumen (purchase decisions).

Hasil penelitian yang telah dilakukan Shukla (2009) menunjukkan bahwa faktor kontekstual mempunyai pengaruh kuat pada keputusan pembelian. Penelitian ini meneliti 
INOBIS: Jurnal Inovasi Bisnis dan Manajemen Indonesia

Volume 2, Nomor 1, Desember 2018

I Made Oka Santika; I Nyoman Nurcaya

bagaimana faktor kontekstual, perpindahan merek berdampak pada keputusan pembelian dimana sampel yang digunakan adalah remaja dan dewasa. Hasil dari penelitian ini menunjukkan bahwa faktor kontekstual berpengaruh positif pada keputusan pembelian. Sedangkan untuk perpindahan merek tidak berpengaruh terhadap keputusan pembelian.

Dalam hasil penelitian yang dilakukan Lubis dan Cindy (2015) menyatakan bahwa brand switching secara positif dan signifikan menentukan keputusan pembelian serta merupakan faktor yang paling mempengaruhi keputusan pembelian daripada variabel lainnya. Fenomena perpindahan merek yang terjadi di kalangan masyarakat sangat penting untuk diteliti, karena dapat dijadikan acuan bagi pemasar untuk dapat bersaing dengan merek-merek yang telah lama berdiri.

Selanjutnya, Penelitian yang dilakukan oleh Sumasastra dan Hendriana (2012) menyatakan bahwa faktor kontekstual berpengaruh positif terhadap keputusan pembelian namun tidak signifikan. Hasil ini tidak sesuai dengan hasil penelitian Shukla (2009) yang menyatakan terdapt pengaruh faktor kontekstual terhadap keputusan pembelian secara signifikan.

Loprang (2015) menyatakan bahwa perpindahan merek sering terjadi pada produkproduk dengan karakteristik keterlibatan pembelian yang rendah. Tingkat keterlibatan produk dikatakan rendah apabila dalam proses pembelian produk konsumen tidak melibatkan banyak faktor dan informasi yang harus ikut dipertimbangkan. Tipe prilaku konsumen yang cenderung melakukan pembelian produk dengan perpindahan merek adalah pengambil keputusan yang bersifat terbatas. Karena jika konsumen tidak puas pasca mengkonsumsi, akan ada kecendrungan mencari merek alternatif lain untuk kelanjutannya.

Perpindahan merek terjadi saat dimana seorang konsumen atau sekelompok konsumen berpindah kesetiaan dari satu merek sebuah produk tertentu ke merek produk lainnya. Menurut Junaidi dkk., (2002) dalam Loprang (2015), perpindahan merek merupakan gambaran dari beralihnya konsumen dari suatu produk ke produk lainnya. Hal ini disebabkan karena konsumen melakukan perbandingan antara merek satu dengan merek yang lain pada saat ia mengevaluasi merek tertentu atau pada saat ia membentuk sikapnya terhadap merek (Laroche et al., 1994 dalam Loprang 2015).

Menurut penelitian yang dilakukan Chen et al., 2016 bahwa konsumen/pelanggan melakukan pembelian dengan mengejar mode atau mengikuti trend modern dan pengaruh orang lain. Dalam lingkungan masyarakat yang menggunakan operator seluler dan hampir semua kalangan pernah melakukan penggantian operator telepon selulernya dengan mengikuti trend terbaru (gaya hidup) dan menggantinya ketika masing-masing operator menawarkan produknya dengan keunggulannya masing-masing. Pada saat ini industri telekomunikasi seluler berbasis GSM diisi oleh lima pemain utama yaitu : Telkomsel, Indosat Ooredoo, Tri, XL Axiata, dan Smartfren.

Berdasarkan Tabel 1 pelanggan operator seluler, dapat dilihat bahwa terdapat persaingan yang cukup ketat dari operator seluler yang ada di Indonesia. Masing-masing operator menawarkan promosi yang menarik seperti periklanan pada media cetak dan elektronik, promosi penjualan, penjualan langsung misalkan di sekolah dengan mendirikan stand untuk meningkatkan jumlah pelanggan operator seluler. Telkomsel merupakan salah satu operator yang memiliki pelanggan terbanyak. Perusahaan jasa telekomunikasi tersebut masih menjadi pemimpin pasar operator seluler di Indonesia. Terlihat bahwa pelanggan Telkomsel berjumlah 157,4 juta atau sekitar 46 persen dari total pelanggan seluler di Tanah Air. Telkomsel mampu mengungguli operator lainnya karena memiliki base transceiver station (BTS) terluas hingga ke daerah pelosok Nusantara. 
INOBIS: Jurnal Inovasi Bisnis dan Manajemen Indonesia

Volume 2, Nomor 1, Desember 2018

I Made Oka Santika; I Nyoman Nurcaya

\section{Tabel 1. Pelanggan Operator Seluler di Indonesia 2016 Operator Seluler Jumlah Pelanggan Operator Seluler}

\begin{tabular}{lr} 
Smartfren & 12 Juta \\
XL Axiata & 46 Juta \\
Tri & 55,5 Juta \\
Indosat Ooredoo & 80,5 Juta \\
Telkomsel & 157,4 Juta \\
\hline
\end{tabular}

Sumber : abatasa, 2016

Beberapa anomali terlihat dari pelanggan operator seluler Indonesia, masyarakat cenderung menggunakan lebih dari satu kartu telepon sehingga jumlah pelanggan operator seluler melebihi jumlah populasi masyarakat Indonesia. Jumlah penduduk Indonesia hanya sekitar 250 juta, namun pelanggan operator seluler di Indonesia lebih dari 300 juta pelanggan.

Anomali ini secara tidak langsung memberikan keuntungan bagi bisnis operator seluler. Keuntungan tersebut dapat dimaksimalkan dengan meningkatkan potensi kualitas produk dan inovasinya agar mendapatkan perhatian pelanggan yang pada dasarnya konsumen mudah terbujuk serta mudah melakukan perpindahan operator seluler (brand switching) karena dianggap memberikan benefit terbanyak bagi mereka.

Dalam survey yang dilakukan terhadap 20 orang konsumen yang menggunakan operator seluler di Kota Denpasar, diperoleh hasil bahwa keseluruhan konsumen tersebut pernah melakukan perpindahan merek dalam pembelian operator seluler. Hal ini menunjukkan bahwa fenomena perpindahan merek dalam pengambilan keputusan pembelian operator seluler terjadi di Kota Denpasar.

Rumusan permasalahan dalam penelitian ini adalah bagaimana pengaruh faktor kontekstual dan brand switching terhadap keputusan pembelian. Sedangkan tujuan dari penelitian ini adalah untuk menjelaskan bagaimana pengaruh faktor kontekstual dan brand switching terhadap Keputusan Pembelian.

\section{Landasan Teori}

\subsection{Perilaku konsumen}

Perilaku konsumen adalah studi tentang individu, kelompok, atau organisasi dan proses yang mereka gunakan untuk memilih, aman, penggunaan, dan membuang produk, jasa, pengalaman, atau ide untuk memuaskan kebutuhan dan dampak bahwa proses ini terhadap konsumen dan masyarakat (Laddha dan Mayur, 2015). Kotler dan Amstrong (2008:159), mengartikan perilaku konsumen sebagai perilaku pembelian konsumen akhir, baik individu maupun rumah tangga, yang membeli produk untuk konsumsi personal. Suprapti (2010:2), mendefinisikan perilaku konsumen sebagai perilaku yang ditujukkan oleh konsumen dalam mencari, membeli, menggunakan, mengevaluasi, dan membuang produk, dan jasa yang diharapkan akan memenuhi berbagai kebutuhannya. Jadi, perilaku konsumen dapat didefinisikan sebagai tindakan dan kegiatan individu dalam pembelian suatu produk untuk memenuhi kebutuhan dan keinginannya. Seorang pemasar perlu mempelajari dan memahami apa yang dibutuhkan dan diinginkan konsumen, karena konsumen memiliki banyak keragaman yang menarik. Hal tersebut yang menyebabkan setiap kebutuhan dan keinginan konsumen berbeda-beda. 
INOBIS: Jurnal Inovasi Bisnis dan Manajemen Indonesia

Volume 2, Nomor 1, Desember 2018

I Made Oka Santika; I Nyoman Nurcaya

Menurut Kotler dan Amstrong (2012:158), pada tahap permulaan, para pemasar dapat memperoleh suatu pengertian yang jelas mengenai konsumen, melalui pengalaman sehari-hari pada waktu menjual sesuatu kepada konsumen. Para pemasar harus memahami mengapa dan bagaimana konsumen mengambil keputusan konsumsi, sehingga pemasar dapat merancang strategi pemasaran dengan lebih baik. Pemasar yang mengerti perilaku konsumen akan mampu memperkirakan bagaimana kecenderungan konsumen untuk bereaksi terhadap informasi yang diterimanya, sehingga pemasar dapat menyusun strategi pemasaran yang sesuai. Gambar 1.

Kotler dan Amstrong (2012:158), menggambarkan model perilaku pembeli seperti pada

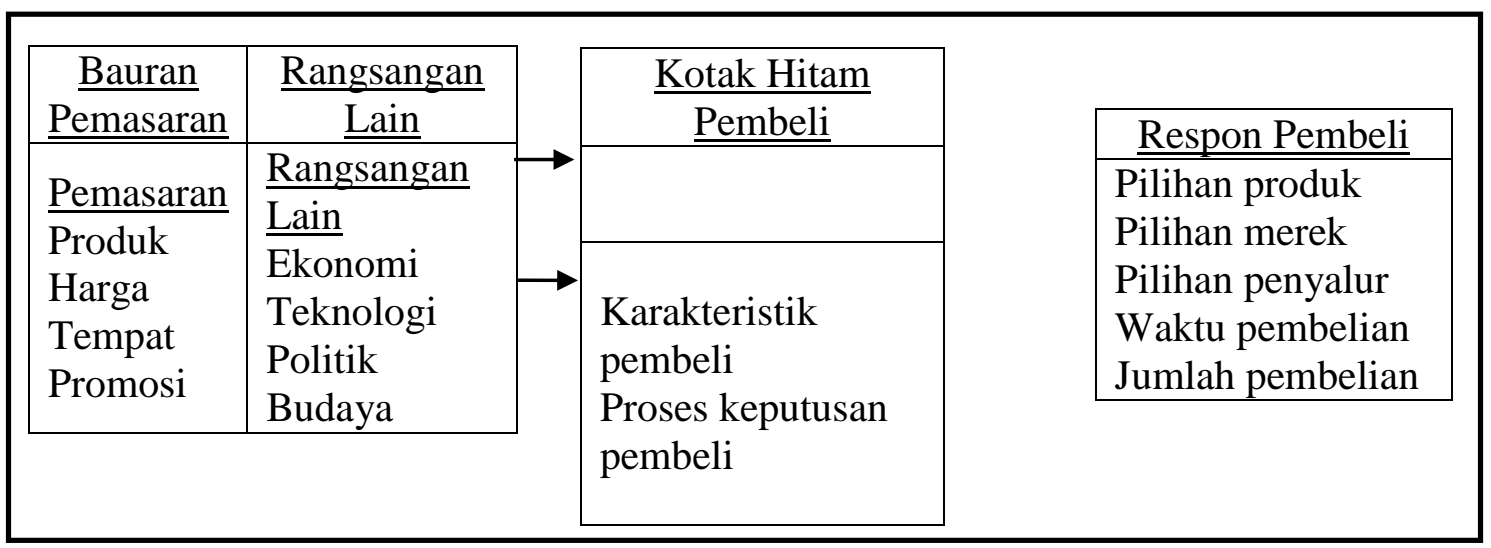

Gambar 1. Perilaku Pembelian

Sumber: Kotler dan Amstrong (2012:158).

\subsection{Keputusan pembelian}

Menurut Kotler dan Keller (2009:184), keputusan pembelian seseorang merupakan hasil dari suatu proses yang terdiri dari lima tahapan yaitu pengenalan, kebutuhan, pencarian informasi, pengevaluasian alternatif, keputusan pembelian, dan perilaku setelah pembelian itu sendiri. Keputusan pembelian juga dipengaruhi oleh faktor psikologis dan karakteristik konsumen itu sendiri (M S Pane dan Rini, 2011)

Verina (2014) mengemukakan bahwa perilaku konsumen yang ditunjukkan dalam pencarian akan pembelian, penggunaan, pengevaluasian, dan penggantian produk dan jasa diharapakan dapat memuaskan kebutuhan konsumen. Menurut Khuong et al., 2016 keputusan pembelian adalah proses dan aktifitas individual yang berikut serta saat penentuan, memperoleh, menerima dan menolak produk maupun jasa.

\subsection{Faktor kontekstual}

Contextual diartikan sebagai sesuatu yang berhubungan atau yang ditentukan dengan atau dalam konteks. Sementara context itu sendiri diartikan sebagai sekumpulan akta atau keadaan yang mengelilingi situasi atau kejadian (Kusmantini, 2011).

Faktor kontekstual sebagai latar belakang yang lengkap dari kehidupan seorang individu dan bagaimana menjalankannya (World Health Organization dalam Sumasastra, 2012). Faktor kontekstual dibagi menjadi dua komponen, yaitu faktor lingkungan dan faktor pribadi. 
INOBIS: Jurnal Inovasi Bisnis dan Manajemen Indonesia

Volume 2, Nomor 1, Desember 2018

I Made Oka Santika; I Nyoman Nurcaya

Faktor kontekstual merupakan berbagai faktor yang dapat mempengaruhi keputusan yang di ambil oleh konsumen, yaitu faktor kebudayaan, sosial, personal dan psikologis sehingga mempengaruhi citra diri, gaya hidup dan pola konsums.

\subsection{Brand switching}

Brand Switching merupakan proses beralih dari satu produk ke produk lain tetaapi dalam kategori yang sama oleh konsumen (Afzal et al., 2013). Brand Switching ditandai dengan adanya perbedaan signifikan antar merek. Konsumen dalam hal ini tidak mengetahui banyak mengenai kategori produk yang ada. Para pemasar dengan demikian perlu mendiferensiasikan keistimewaan mereknya untuk menjelaskan merek tersebut. Perpindahan merek (brand switching) juga ditandai dengan keterlibatan yang rendah (low involvement). Konsumen tidak melalui tahap-tahap keyakinan, sikap atau perilaku yang normal. Konsumen tidak secara ekstensif mencari informasi mengenai merek, melainkan merupakan penerima informasi pasif. Konsumen tidak membentuk keyakinan merek tetapi memilih suatu merek karena merek tersebut terasa akrab (Kurniawan, 2016).

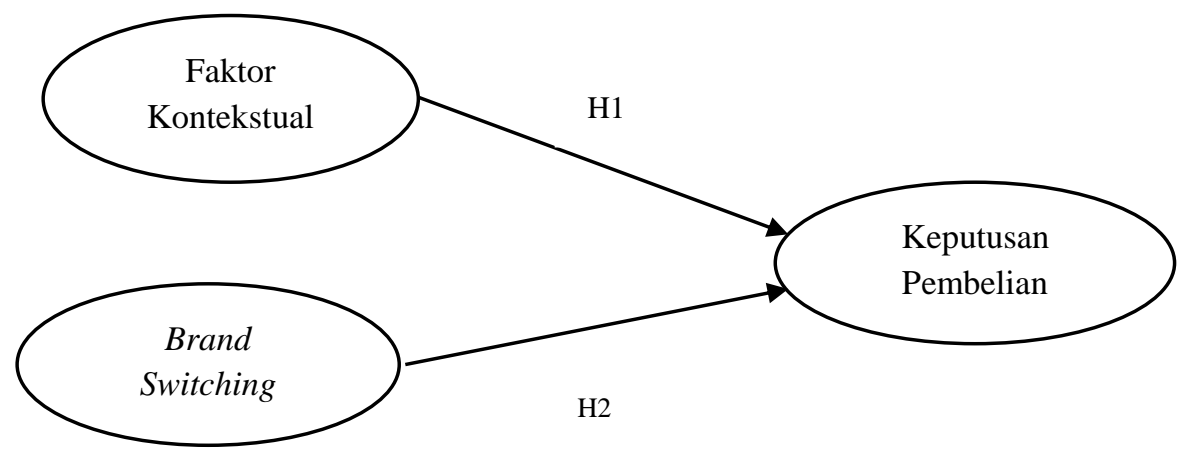

Gambar 2 Kerangka Konseptual Penelitian Pengaruh Faktor Kontekstual dan Brand Switching Terhadap Keputusan Pembelian

\subsection{Hipotesis Penelitian}

1) Faktor kontekstual berpengaruh positif dan signifikan terhadap keputusan pembelian konsumen.

2) Brand switching berpengaruh positif dan signifikan terhadap keputusan pembelian konsumen.

\section{Metode Penelitian}

Penelitian ini dilakukan di Kota Denpasar, Provinsi Bali. Populasi yang digunakan pada penelitian ini adalah konsumen yang melakukan keputusan pembelian operator seluler di Kota Denpasar dengan jumlah populasi yang tidak diketahui secara pasti (invinite). Penentuan sampel ini menggunakan metode non-probability sampling dengan metode purposive sampling yakni teknik pengambilan sampel yang tidak memberi peluang / kesempatan yang sama bagi setiap unsur atau anggota populasi untuk dipilih menjadi sampel. Teknik nonprobability sampling dengan penentuan sampel dengan pertimbangan kriteria seperti usia minimal 18 tahun, pernah melakukan pembelian operator seluler, menggunakan lebih dari 
INOBIS: Jurnal Inovasi Bisnis dan Manajemen Indonesia

Volume 2, Nomor 1, Desember 2018

I Made Oka Santika; I Nyoman Nurcaya

satu operator seluler dan pernah mengganti operator selulernya. Jumlah sampel yang dipergunakan adalah 120 orang.

Data dikumpulkan dengan menggunakan kuesioner yang berisi pengukuran variabel dengan Skala Likert. Skala ini mengukur sikap, pendapat, dan persepsi seseorang atas sebuah fenomena. (Sugiyono, 2013:132). Jawaban dari setiap pertanyaan memiliki skor tersendiri dimulai dari sangat tidak setuju (Skor 1) sampai sangat setuju (Skor 5)

Variabel dalam penelitian ini beserta indikatornya disajian pada Tabel 2.

Tabel 2. Operasional Variabel Penelitian

\begin{tabular}{|c|c|c|c|c|}
\hline No & $\begin{array}{l}\text { Identifikasi } \\
\text { Variabel }\end{array}$ & Variabel & Indikator & Sumber \\
\hline \multirow[t]{4}{*}{1} & \multirow[t]{4}{*}{$\begin{array}{l}\text { Variabel } \\
\text { Terikat }\end{array}$} & \multirow{4}{*}{$\begin{array}{l}\text { Keputusan } \\
\text { pembelian } \\
\text { (Y) }\end{array}$} & $\begin{array}{l}\text { a) Pengenalan } \\
\text { kebutuhan (Y.1) }\end{array}$ & \multirow[t]{4}{*}{$\begin{array}{l}\text { Mulyadi dkk } \\
\text { (2012) }\end{array}$} \\
\hline & & & $\begin{array}{l}\text { b) Pencarian informasi } \\
\text { (Y.2) }\end{array}$ & \\
\hline & & & $\begin{array}{l}\text { c) Evaluasi alternatif } \\
\text { (Y.3) }\end{array}$ & \\
\hline & & & $\begin{array}{l}\text { d) Pembelian dan } \\
\text { kepuasan (Y.4) }\end{array}$ & \\
\hline \multirow[t]{11}{*}{2} & \multirow{11}{*}{$\begin{array}{l}\text { Variabel } \\
\text { Bebas }\end{array}$} & \multirow{5}{*}{$\begin{array}{c}\text { Faktor } \\
\text { kontekstual } \\
\left(\mathrm{X}_{1}\right)\end{array}$} & a) Keluarga $\left(X_{1} .1\right)$ & \multirow{5}{*}{$\begin{array}{c}\text { Sumasastra } \\
\text { dan Hendriana } \\
(2012)\end{array}$} \\
\hline & & & b) Teman $\left(\mathrm{X}_{1} .2\right)$ & \\
\hline & & & c) Gaya hidup ( $\left.\mathrm{X}_{1} .3\right)$ & \\
\hline & & & d) Citra diri $\left(X_{1} .4\right)$ & \\
\hline & & & e) Citra merek $\left(X_{1.5}\right)$ & \\
\hline & & \multirow{6}{*}{$\begin{array}{l}\text { Brand } \\
\text { switching } \\
\quad\left(\mathrm{X}_{2}\right)\end{array}$} & $\begin{array}{l}\text { a) Rasa penasaran } \\
\left(\mathrm{X}_{2} .1\right)\end{array}$ & \multirow{6}{*}{$\begin{array}{c}\text { Sumasastra } \\
\text { dan Hendriana } \\
\text { (2012) }\end{array}$} \\
\hline & & & $\begin{array}{l}\text { b) Kemudahan untuk } \\
\text { beralih }\left(X_{2} .2\right)\end{array}$ & \\
\hline & & & $\begin{array}{l}\text { c) Banyaknya pilihan } \\
\left(\mathrm{X}_{2} .3\right)\end{array}$ & \\
\hline & & & d) Promosi $\left(\mathrm{X}_{2} .4\right)$ & \\
\hline & & & e) Harga $\left(X_{2.5}\right)$ & \\
\hline & & & $\begin{array}{l}\text { f) Kekecewaan pada } \\
\text { produk yang } \\
\text { digunakan saat ini } \\
\left(\mathrm{X}_{2} .6\right)\end{array}$ & \\
\hline
\end{tabular}

Sumber : Mulyadi dkk (2012), Sumasastra dan Hendriana (2012)

Teknik analisis yang dipergunakan dalam penelitian ini adalah Analisis Regresi Linier Berganda. 
INOBIS: Jurnal Inovasi Bisnis dan Manajemen Indonesia

Volume 2, Nomor 1, Desember 2018

I Made Oka Santika; I Nyoman Nurcaya

\section{Hasil dan Pembahasan}

1) Uji validitas dan reliabilitas instrumen

Suatu instrumen dikatakan valid jika korelasi (r) antara skor faktor dengan skor total bernilai positif dan nilainya lebih dari $0,30(\mathrm{r}>0,3)$. Hasil uji validitas pada Tabel 3 menunjukkan bahwa seluruh indikator memiliki koefisien korelasi terhadap totalnya lebih besar dari 0,30 sehingga seluruh indikator tersebut telah memenuhi syarat validitas data.

Tabel 3. Uji Validitas

\begin{tabular}{cccc}
\hline Variabel & Instrumen & $\begin{array}{c}\text { Pearson } \\
\text { Correlation }\end{array}$ & Keterangan \\
\hline Keputusan & Y.1 & 0,836 & Valid \\
Pembelian & Y.2 & 0,802 & Valid \\
& Y.3 & 0,897 & Valid \\
Faktor & Y.4 & 0,821 & Valid \\
Kontekstual & X1.1 & 0,738 & Valid \\
(X1) & X1.3 & 0,866 & Valid \\
& X1.4 & 0,811 & Valid \\
Brand & X1.5 & 0,758 & Valid \\
Switching (X2) & X2.1 & 0,633 & Valid \\
& X2.3 & 0,831 & Valid \\
& X2.4 & 0,831 & Valid \\
& X2.5 & 0,731 & Valid \\
& X2.6 & 0,820 & Valid \\
& 0,863 & Valid \\
&
\end{tabular}

Sumber : data primer diolah, 2017

Suatu instrumen dikatakan reliabel, jika instrumen tersebut memiliki nilai Alpha Cronbach lebih dari 0,70. Adapun hasil dari uji reliabilitas dapat ditunjukkan pada Tabel 4 be

Tabel 4.

Uji Reliabilitas

\begin{tabular}{ccc}
\hline Variabel & Cronbach's Alpha & Keterangan \\
\hline Keputusan Pembelian (Y) & 0,859 & Reliabel \\
Faktor Kontekstual (X1) & 0,834 & Reliabel \\
Brand Switching (X2) & 0,879 & Reliabel \\
\hline
\end{tabular}

Sumber : data primer diolah, 2017

Hasil uji reliabilitas yang disajikan dalam Tabel 4 menunjukkan bahwa ketiga instrumen penelitian yaitu memiliki koefisien Cronbach's Alpha lebih dari 0,70. Hal ini dapat dikatakan bahwa semua instrumen reliabel sehingga dapat digunakan untuk melakukan penelitian. 
INOBIS: Jurnal Inovasi Bisnis dan Manajemen Indonesia

Volume 2, Nomor 1, Desember 2018

I Made Oka Santika; I Nyoman Nurcaya

2) Hasil analisis

Model analisis regresi linier berganda digunakan untuk mencari koefisien regresi yang akan menentukan apakah hipotesis yang dibuat akan diterima atau ditolak. Hasil analisis regresi linier berganda disajikan pada Tabel 5.

Tabel 5. Hasil Analisis Regresi Linier Berganda

\begin{tabular}{lccccc}
\hline \multirow{1}{*}{ Model } & \multicolumn{2}{c}{$\begin{array}{c}\text { Unstandardized } \\
\text { Coefficients }\end{array}$} & $\begin{array}{c}\text { Standardized } \\
\text { Coefficients }\end{array}$ & T & Sig. \\
\cline { 2 - 4 } & $\mathrm{B}$ & Std.Error & Beta & & \\
\hline 1 (Constant) & 4,906 & .891 & & 5.508 & .000 \\
Faktor Kontekstual & .462 & .067 & .619 & 6.936 & .000 \\
Brand Switching & .126 & .055 & .206 & 2.312 & .023 \\
\hline R Square & $: 0,624$ & & & & \\
F Statistik & $: 96,977$ & & & & \\
Signifikansi Uji F & $: 0,000$ & & & & \\
\hline
\end{tabular}

Sumber : data primer diolah, 2017

Pelaporan hasil analisis Regresi Linier Beganda pada Tabel 5 dapat digunakan untuk menyusun persamaan regresi, yaitu:

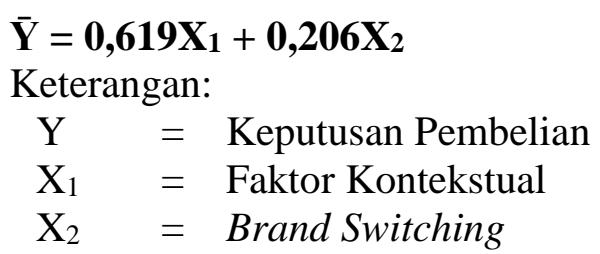

Hasil pengujian yang disajikan pada Tabel 5 menunjukkan koefisien F sebesar 96,977 dengan signifikansi (p) sebesar 0,000. Signifikansi uji F yang lebih kecil dari 0,05 menunjukkan bahwa model regresi yang diperoleh adalah layak menggambarkan model penelitian yang dirumuskan. Dengan demikian, model tersebut bisa untuk ditindaklajuti untuk proses berikutnya.

Data juga menunjukkan bahwa koefisien $R$-square diperoleh sebesar 0,624. Ini menunjukkan 62,4 persen variabel Keputusan Pembelian dipengaruhi oleh variabel Faktor Kontekstual, dan Brand Switching sedangkan sisanya 37,6 persen dipengaruhi oleh faktor lainnya yang tidak masuk dalam penelitian ini.

\subsection{Pengaruh Faktor Kontekstual terhadap Keputusan Pembelian Operator Seluler di Kota Denpasar}

Pengujian hipotesis pada pengaruh Faktor Kontekstual terhadap Keputusan Pembelian menunjukkan bahwa Faktor Kontekstual memiliki koefisien regresi positif 0,619 dengan signifikansi uji t sebesar 0,000. Ini menunukkan bahwa faktor kontekstual berpengaruh positif signifikan terhadap Keputusan Pembelian. Semakin tinggi pengaruh dari Faktor Kontekstual terhadap konsumen, maka semakin tinggi pula Keputusan Konsumen dalam melakukan pembelian operator seluler di Kota Denpasar. 
INOBIS: Jurnal Inovasi Bisnis dan Manajemen Indonesia

Volume 2, Nomor 1, Desember 2018

I Made Oka Santika; I Nyoman Nurcaya

\subsection{Pengaruh Brand Switching terhadap Keputusan Pembelian Operator Seluler di Kota Denpasar}

Pengujian hipotesis pada pengaruh Brand Switching terhadap Keputusan Pembelian menunjukkan bahwa Brand Switching secara signifikansi berpengaruh positif terhadap Keputusan Pembelian. Hal ini ditunjukkan oleh koefisien regresi variabe Brand Switching sebesar 0,206 dengan signifikansi uji $\mathrm{t}$ sebesar 0,023. Ini berarti semakin baik Brand Switching yang dilakukan oleh konsumen, maka semakin tinggi Keputusan Pembelian operator seluler di Kota Denpasar.

Berdasarkan hasil penelitian yang diperoleh, terdapat beberapa implikasi yang dihasilkan. Pertama, di dalam variabel faktor kontekstual didapat hasil bahwa indikator "pembelian operator seluler yang berdasarkan kemauan individu dan yang memiliki citra merek yang baik di pasaran" menjadi indikator yang memiliki nilai rata-rata tertinggi dibandingkan indikator lainnya, ini berarti bahwa responden mengetahui bahwa munculnya keputusan pembelian dipicu oleh kemauan individu dan citra merek yang baik di pasaran.

Implikasi yang kedua yaitu di dalam variabel brand switching didapatkan hasil bahwa indikator "kekecewaan pada produk operator seluler", menjadi indikator yang memiliki nilai rata-rata tertinggi dibandingkan dengan indikator lainnya. Ini berarti bahwa apabila responden merasa kecewa pada produk operator seluler sebelumnya maka responden akan melakukan keputusan pembelian operator seluler yang lainnya.

\section{Simpulan}

Faktor Kontekstual secara signifikan berpengaruh positif terhadap Keputusan Pembelian. Ini berarti semakin tingginya pengaruh dari Faktor Kontekstual terhadap konsumen, maka semakin baik pula Keputusan Konsumen dalam melakukan pembelian operator seluler di Kota Denpasar. Brand Switching secara signifikan berpengaruh positif terhadap Keputusan Pembelian. Ini berarti semakin baik Brand Switching yang dilakukan oleh konsumen, maka semakin baik Keputusan Pembelian operator seluler di Kota Denpasar.

Pihak penyedia layanan operator seluler diharapkan mampu memasarkan produknya lebih kepada konsumen (keluarga) dimana keluarga dapat mempengaruhi keputusan pembelian konsumen, yaitu dengan menyediakan varian paket yang dapat lebih menguntungkan konsumen (keluarga).

Penelitian mendatang disarankan untuk menyertakan brand operator seluler yang sebelum dan sesudah konsumen gunakan, sehingga penelitian selanjutnya dapat menjadi lebih sempurna.

\section{Referensi}

Afzal, Sarwat, Aamir Khan Chandio, Sania Shaikh, Muskan Bhand, Bais Ali Ghumro dan Anum Kanwal Khuhro. 2013. Factors Behind Brand Switching in Cellular Networks. International Journal of Asian Social Science, Vol. 3, No. 2, pp. 299-307

Khasanah, Aulia Uswatun dan Rini Kuswati. 2013. Analisis Faktor-Faktor Mempengaruhi Perpindahan Merek pada Produk Smartphone. Jurnal Manajemen dan Bisnis, Vol. 17, No. 2, Hal: 123-131

Khuong, Mai Ngoc dan Hoang Thi My Duyen. 2016. Personal Factors Affecting Consumer Purchase Decision towards Men Skin Care Products-A Study in Ho Chi Minh City, Vietnam. International Journal of Trade, Vol. 7, No. 2, pp. 44-49 
INOBIS: Jurnal Inovasi Bisnis dan Manajemen Indonesia

Volume 2, Nomor 1, Desember 2018

I Made Oka Santika; I Nyoman Nurcaya

Kotler, Philip dan Gary Armstrong. 2012. Prinsip-prinsip Pemasaran. Edisi 13. Jilid 1. Jakarta: Erlangga.

Kurniawan, Andrie. 2016. Perilaku Brand Switching Konsumen dalam Pembelian Produk Kartu SIM HP CDMA. Jurnal Administrasi Kantor, Vol. 4, No. 1, pp. 235-264

Kusmantini, Titik, Yekti Utami dan Tri Wahyuningsih. 2011. Analisis Faktor-Faktor Kontekstual Proses Pengembangan Produk dan Dampaknya pada Kualitas Produk Baru. Vol. 5, No. 2, pp. 116-128

Laddha, S., and Mayur Malviya. 2015. Green Marketing and Its Impact on Consumer Buying Behavior. NBR E-Journal, 1(1), pp: 1-7.

Loprang, Jilly Vanessi. 2015. Analisis Faktor-Faktor yang Dipertimbangkan Konsumen dalam Perpindahan Merek Mie Instan (Studi pada Mahasiswa di Kota Manado). Jurnal Riset Bisnis dan Manajemen, Vol. 3, No. 4, pp. 332-345

Lubis, Atur Tetty dan Cindy Karina Anggy Palibutan. 2015. The Impact of Contextual Factors, Brand Loyalty and Brand Switching On Purchase Decision of Mineral Water In Convenience Store. Journal of Business Strategy and Executin, Vol. 8, No. 1, pp. $1-24$

Makwana, Khushboo, Nidhi Sharma dan Swaranjeet Arora. 2014. Factors Influencing Consumer Brand Switching Behavior in Telecommunication Industry:An Empirical Study. Prestige e-Journal of Management and Research, Vol. 1

Mantiaha Gratia F. 2016. Pengaruh Pemasaran Hijau Terhadap Perilaku Pembelian Konsumen (Penelitian Pada The Body Shop Manado). Jurnal EMBA, 4(2), h: 58-67.

Mulyadi, Dedi, Kosasih dan Siska P Saputri. 2012. Analisis Merek Terhadap Keputusan Pembelian Kartu Perdana As di SMAN 4 Karawang. Jurnal Manajemen, Vol. 10, No. 1, pp. 993-1001

Pantawis, Setyo dan Rudi Suryo Kristanto. 2016. Analisis Brand Switching Media Sosial (Studi pada Penggunaan Media Sosial sebagai Sarana Berbisnis di Kalangan Mahasiswa di Kota Semarang). Jurnal EBBANK, Vol. 7, No. 2, pp. 111-123

Prastiyo, Yuni. 2016. Pengaruh Green Marketing Tool's Terhadap Perilaku Pembelian Konsumen. E-Jurnal Manajemen Unud, 5(6), h: 3449-3475.

Shukla, P. 2009. Impact of contextual factors, brand loyalty and brand switching on purchase decision. Journal of Consumer Marketing, pp. 1-30

Suharseno, Teguh, Riskin Hidayat dan Dian Ayu Liana Dewi. 2013. Pengaruh Ketidakpuasan Konsumen dan Karakteristik Kategori Produk Terhadap Keputusan Perpindahan Merek dengan Kebutuhan Mencari Variasi Sebagai Variabel Moderasi. Jaurnal Buletin Studi Ekonomi, Vol. 18, No. 2, pp. 176-182

Sumasastra, Fandy dan Evelyn Hendriana. 2012. Pengaruh Faktor Kontekstual Terhadap Perilaku Pembelian Smartphone Blackberry. DeReMa Jurnal Manajemen, Vol. 7, No. 2, pp. $1-17$

Suprapti, Ni Wayan. 2010. Perilaku Konsumen. Denpasar: Udayana University Press.

Wijaya, Yoni Servika, Achmad Fauzi DH., dan Sunarti. 2014. Pengaruh Atribut Produk terhadap Keputusan Perpindahan Merek (Survei pada Mahasiswa Fakultas Ilmu Administrasi Angkatan 2011/2012 Universitas Brawijaya yang Beralih Merek ke Smartphone Samsung). Jurnal Administrasi Bisnis, Vol. 12, No. 2, Hal: 1-7 